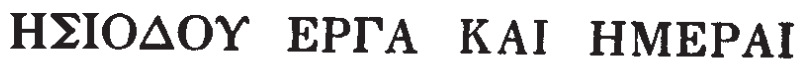

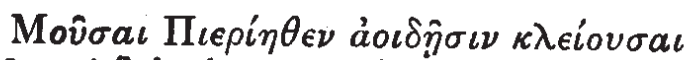

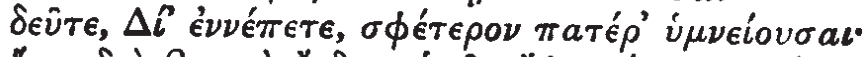

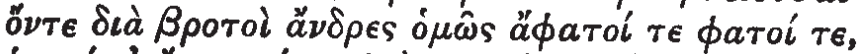

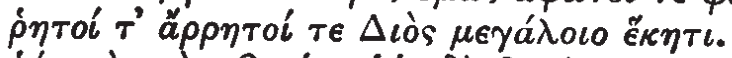

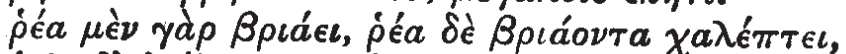

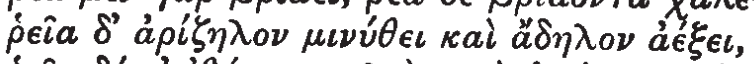

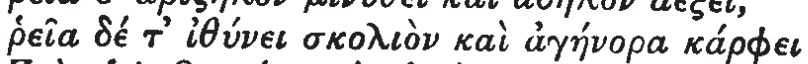

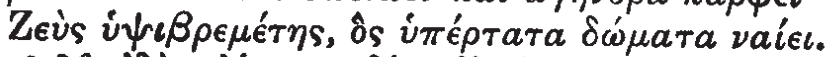

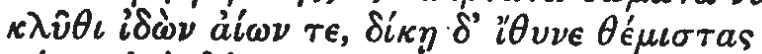

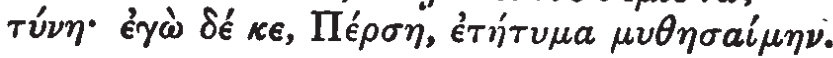

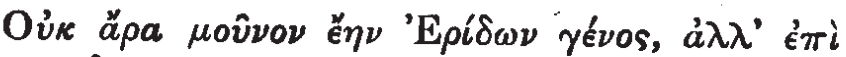
yaî̀

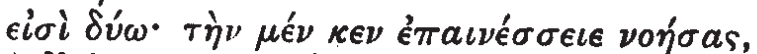

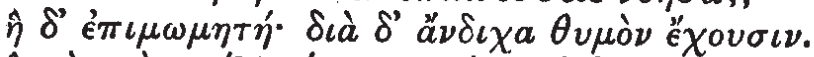

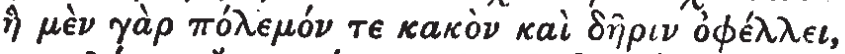

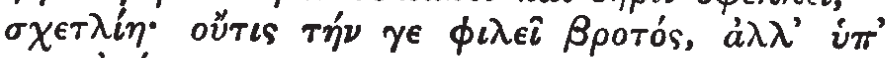

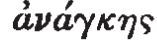

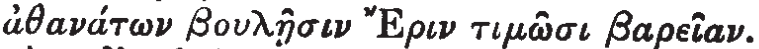

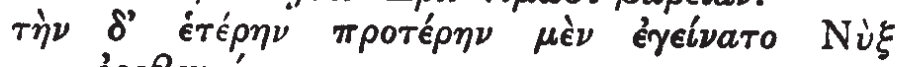
$\dot{\epsilon} \rho \in \beta \epsilon \nu \nu \eta^{\prime}$,

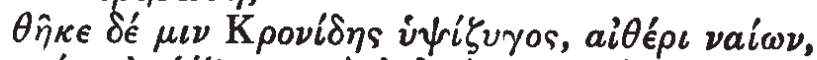

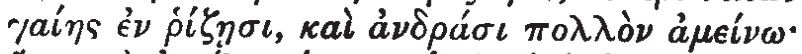

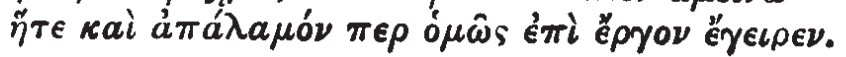




\title{
Hesiódicas erga: dois momentos
}

\author{
Antonio Medina Rodrigues
}

Hesíodo, um dos grandes poetas da Antigüidade grega (era arcaica, $700^{\circ}$ C.), é o autor da Teogonia e de Os Trabalhos e os Dias. Foi o primeiro poeta ocidental a mostrar-se nominal e ostensivamente em primeira pessoa. Sua obra é o registro mais completo de sua vida. Os Trabalhos e os Dias têm 828 versos hexamétricos. A matéria, didática e moralizante, desfia-se em algo "associativamente", porém isto não the complica a unidade, nem the dificulta a leitura.

Depois do Proêmio, que contém um apelo para que se cumpram os ditames da justiça, vêm duas grandes partes. Na primeira (1 1-341), e por meio da representação mítica da vida, Hesíodo quer convencer seu irmão de que o mal provém de uma contínua hybris processada no no seio das gerações e raças mais antigas da humanidade. E, contra essa faina da maldade, o remédio, para Hesíodo, é trabalhar. Pois o trabalho é a base da justiça humana, dado que a base divina vem de Zeus. E, como não há salvação fora destas duas, Hesíodo verbera os que devoram as poupanças dos incautos ou tolos (um deles é Perses, o irmão), por meio de pendências e discussões em praça pública. É mesmo possível que, a essa altura, Hesíodo polemize com a velha prática do controle discursivo e aristocrata da sociedade, coisa comum na Grécia arcaica, e por sinal testemunhada em Homero, sobretudo na Odisséia. Hesíodo criou-se na Beócia, região de austeridade camponesa, pouco afeita aos rompantes do heroísmo. Ele é contra a guerra. E não ostenta nenhum triunfalismo. Nem social, nem racial. 
A segunda parte (342-764) possui caráter mais prático ainda, expresso inclusive na forma de aforismos e conselhos (a condução da vida, o envolvimento com vizinhos, os modos e formas da pecuária, as épocas do ano, as estações, o plantio, a colheita, a economia domésti$\mathrm{ca}$, e até mesmo uma certa resistência contra as incursões no mar).

Gigon, Cornford e outros têm apontado a precocidade de Hesíodo, e a célebre afirmação de Heródoto $(2.53,2)$ segundo a qual Hesíodo e Homero haveriam sido os criadores dos deuses helênicos não faz muito jus à originalidade mental do autor de Os Trabalhos e os Dias. Tal como Hegel ou Vico fizeram vários séculos depois, Hesíodo também partia de um fundamento religioso absoluto. Mas, feito isso, nenhuma outra idéia era aceita se não passasse pelo crivo da experiência. Como um poeta-mestre que foi, ele busca uma verdade, e o mito, sob esse aspecto, é por ele tomado como estímulo e matéria de uma sondagem racional e sistemática. Hesíodo, afinal, objetiva uma história do mundo. Sua aproximação com os pré-socráticos, ainda que efetiva, é um pouco lateral, dado que, para além do pré-socratismo, Hesíodo anuncia que a cultura nasce do trabalho, e isso era novo na Grécia. Hesíodo exalta os lavradores e camponeses. Não por esprit de corps, mas porque de fato esse era o trabalho que ele conhecia, e o único que possibilitava uma totalização harmônica da vida, com os deuses, com os homens, e com a própria natureza. Sua visão, sem embargo de ser "pequeno-burguesa", dado que o bem aí resulta do esforço de cada um em relação a si mesmo, é no mínimo uma visão concreta e dialética: o trabalho, afinal, vai mediando a si mesmo, até cristalizar-se na pura sabedoria. De certa forma, a insistência de Hesíodo na primeira pessoa não o leva ao subjetivismo, ainda que o tivesse colocado nos umbrais da lírica. Hesíodo influenciou Arquíloco, Semônides, Alceu, e até Calímaco, que é bem posterior a estes. 
Ó Musas que, da Piéria, honrais com vossos cantos! A Zeus aqui entoai, com hinos, vosso pai, Por quem os homens são gloriosos ou inglórios, Obscuros ou famosos são mediante Zeus, O que fácil robora, e ao valentão estiola, E ao cabisbaixo exorta, enquanto ao bamba entorta, Pois vibra Zeus o raio, e em altas mansões mora. Ouve e me olha, ó tu: com lei cumpras os tratos. E que eu a Perses narrar possa umas verdades.

\section{As duas}

Na terra, uma só raça de Lutas não houve, Há, porém, duas: uma exaltas, se a conheces, Sendo outra uma execrável. São avessas no ânimo. Só destruições e guerras más faz uma delas, A infame. E homem nenhum a quer, mas, por afãs Fatais dos imortais, a densa Luta louvam. E a outra Luta é a outra Noite quem gerou, E o Cronida, que do alto rege e o ar habita, A enraizou à terra, e a fez melhor aos homens: Até um molenga esta sacode a trabalhar, Pois se ressente de lavrar quem outrem vê Polpudo, a semear esperto, e mais plantar, Gerindo a casa: esse vizinho inveja ao outro, Ao que amealha, eis boa Luta para os homens. Inveja os pares o arquiteto, o ceramista: Aedo inveja aedo, mendigo a mendigo. 
Põe na tua alma, pois, ó Perses, coisas tais.

Tua garra a Luta má não tire do trabalho,

Só para veres e ouvires em praça mil pendências:

Fugaz é a hora das pendências e das rixas,

A quem no lar não tem comida armazenada,

Sazonal, que da terra sai, trigal de Ceres!

Se o tivesses, então farias lutas, rixas,

De olho no alheio, mas tal ato não farias

Outra vez. Nossa rixa, pois, esclareçamos

Mediante as sumas leis, as que provêm de Zeus.

Já dividimos nossa herança, e dela muito

Arrebataste, conduzindo-a, inglório, aos reis

Papões, que nossa causa querem justiçar,

Idiotas, não sabem que mais que o todo é o meio,

E que a fortuna grassa mais em malva e asfódelo!

\section{Pandora e Prometeu}

Guardam os deuses o enigma dos víveres.

Se a lavra toda num só dia produzisses,

Tudo fora fácil: um ano inteiro descansavas.

Sobre a lareira, o teu leme aquecerias,

Fim do lavrar com bois e mulas pacientes!

Isso, porém, irado Zeus nos proibiu

Pois Prometeu de anseios curvos o enganara,

E Zeus aos homens deu desgraças, escondeu-lhes

O fogo, que de novo o Japetionida

Audaz roubou ao sábio Zeus, pra dá-lo aos homens, 
Num cavo nártex, que ele oculta ao deus do raio.

E irado o junta-nuvens disse contra este:

"Ó Japetionida, sabes mais que os outros!

Gozas teu roubo, o ardil que me pregaste

Será um mal para ti, e para os mortais futuros, Fogo não lhes darei, mas pragas, com que todos Se alegrem na alma, a celebrar a sua maldade". Falou, e riu-se o pai dos deuses e dos homens. A Hefesto excelso convocou para que rápido A um misto de água e terra a voz metesse humana, A força também, e, como às deusas, na cútis A forma bela, ardente e virgem. Manda a Atena As lavras do tear de cores ensinar-lhe, E a Afrodite as graças que na fronte ondulam, E o cio ardente, e as ânsias que amaciam membros. E para dar-lhe alma canina, instinto agudo, Indica Hermes, núncio e matador de Argos. Todos cederam ao líder Cronida, Zeus.

E o Coxo insigne logo modelou na terra Casta virgem, consoante os termos do Cronida, Adereços e cintura deu-lhe gláucia Atena, Graças, e deusas e Peithô the põem mil contas De ouro pela cútis, e em torno da qual As belas Horas vernais flores engrinaldam. O porte inteiro lhe compôs Palas Atena. Porém o matador de Argos, breve Núncio, Mentiras nela pôs, e um ânimo fingido, (Como quis Zeus atroador), e a voz Lhe ultima o divo arauto, que à dama chamou Pandora, pois do Olimpo todos moradores Deram-na como um Dom, praga aos que comem pão. Concluso assim o embuste mau, e irretornável, A Epimeteu o Pai envia o Argicida, Leva o núncio o Dom dos deuses. E Epimeteu 
Nem pensa no aviso do irmão: nenhum presente Pegar do Olímpio Zeus, mas, contra, despachá-lo, De volta, não trouxesse um mal para os humanos. Sem juízo aceita, e só compreende o mal agora. Na terra, houvera antigamente estirpes de homens Sem as penúrias, sem as fadigas do esforço, Sem as doenças, que aos humanos servem pragas. Mas a mulher, da jarra manobrando a tampa, Dispersou-as, e aos homens espalhou horrores. Só Esperança em suas celas indeléveis Ficou, sob as beiradas, nem pôde voar. Pois a tampa de novo a jarra bloqueara, (Idéias de Zeus egífero, que ajunta as nuvens) E entre os homens mil sofrenças vão-se alçar, Atufa-se de males oceano, a terra.

Doenças vêm ao dia, mas, quando noturnas, Trazem por conta própria os males aos mortais, E na mudez, pois voz lhes tira o sábio Zeus.

E assim, da síntese de Zeus não há escapar.

\section{Conselhos práticos}

Depois, enfim, que do viver em casa houveres Recolhido, eu te rogo que arranjes um Peão sem família, e uma mulher sem prole (A que há parido é complicada), e um cão com dentes Aguçados não poupes do pão que the deres.

Olha o ladrão, que dorme ao sol e à noite rouba-te!

Dentro, cama e forragens guarda, a fim que haja 
Para mulas e bois o necessário. E então

Deixa tuas servas dar ar fresco a seus joelhos.

Solta teus bois. E quando ao céu Órião e Sirius

Despontarem, e a dedirrósea Aurora vir

O Arcturo, traze as uvas para o corte, ó Perses,

E em casa, sob o sol, as deixes por dez dias,

Mais cinco a que se ensombrem, e, no dia seguinte,

Depõe nas ânforas os dons do ledo Dióniso.

$\mathrm{E}$, enfim, quando se atufem as Plêiades e ĺades

E o poderio de Órion, não esqueças da hora

Das sementeiras. E que o chão nos dê de dobro.

E se te assalta o afã dos ínvios velejares,

Quando as Plêiades, ao fugirem da possante

Força de Órion tombam no mar enevoado,

Quando resmungam hálitos de todos ventos,

Lembra-te então de trabalhar a terra, eu digo-te:

Sem que te metas com navios em mar de vinho.

Desvia a nave para a praia e, por todos

Os lados calça-a com pedras, e que assim

Da ira úmida dos ventos não se alveje,

$E$, tirando o batoque, não se irá puir

Coa chuva de Zeus. Põe na tua casa em ordem

Teus cordoames todos e da singradora

Nau dobra as asas e o bem lavrado timão

Sobre a lareira eleva, aguarda a hora da voga

Até que venha, e só então há que levar-se

Ao mar a breve nau, com carga comedida,

A fim que ao lar retornes com proveito,

Qual fez meu pai e o teu, ó Perses bobalhão,

Vogando em barcos a ganhar a dura vida, 
E que após muito mar andado aqui chegara, Tendo largado em negra nau Cumas Eólida, Não por fugir obscuro, por riqueza ou ouro, Mas pela má pobreza que aos mortais doa Zeus.

Fixou-se junto ao Hélicon, vila em penúrias, Ascra, ruim no frio, no estio, sem nada bom. Lembra-te, pois, ó Perses, que os trabalhos todos Têm sua hora, sobretudo a marinhagem. À nau, belas palavras, e ao veleiro as cargas! Enquanto cresça a carga, o lucro ao lucro alarga, E se em comércio ao investires teu instinto, Escapar quiseres da fome ou de outras dívidas, Do mar que estronda todo esquema te darei, Sem nada sofismar de barcas ou cargueiros, Pois numa nau jamais o ancho mar andei, Senão de Áulida até Eubéia, onde os Aqueus No inverno aquoso muitos povos congregaram Para zarpar contra lilion de belas mulheres. De lá parti, para as contendas de Anfidamas! Garanto que ganhei com asas uma trípode, Que consagrei, por fim, às Musas helicônias, Lá onde elas ao cantar mavioso me iniciaram.

Esse é meu tino com as naus bem pregueadas,

Porém de Zeus da égide eu direi a idéia

Pois hino sem rival as Musas me ensinaram.

$(600-662)$

(Texto em grego: Hugh G. Evelyn-White, M.A. Hesiod the homeric hymns and homerica. Harvard University Press. 1977). 